Article

\title{
Issues of Strategic Digital City
}

\author{
Sergio Silva Ribeiro \\ Department of Business Adminsitration, Briercrest College and Seminary, Caronport, SK SOH 0S0, Canada; \\ sribeiro@briercrest.ca
}

Received: 11 June 2019; Accepted: 29 September 2019; Published: 3 October 2019

Abstract: In the contemporary era of information, it is a critical challenge for city managers to meet the demands of their citizens at the same pace as the development of its information technology resources. Guarapuava is an example of a centennial town that has been predominantly agricultural and now seeks to adjust to the population density and the new information age. Much like Guarapuava, many cities in Brazil and around the world are in a similar condition. The new reality of many towns is challenging for municipal managers. Strategic digital city is the application of information technology resources in the management of the city. The objective of this paper is to analyse the decision-making processes, strategies, public services, information technologies, and relationships with strategic digital city issues in the city of Guarapuava, Parana, Brazil. Using a survey methodology based on the research variables, we showed that the municipality has informal characteristics of the concept of a strategic digital city. Based on the results, the evidence domain types in the city are predominant for internet and colleagues inside the organization on a daily base. Google scholar is the most consulted research source of evidence. Respondents well know the term methodology. Their attitudes towards scientific research show that it is essential for managers and that managers are aware of how to use that technology. Related to evidence-based management the respondents, in general, agreed that using by evidence-based practices, managers can improve the quality of their work, and that this should be part of their formal education. Citizens should be utilised more as a source of evidence as well, as they are the users of the institutions. The strategies are more focused on the government and its administration, however, these strategies could include areas like science and technology. The city offers electronic public services to improve citizens lives, and to be more transparent in sharing information through these alternative channels. The analysis revealed the effort of the town to include citizens in the digital era, and its attempt to connect with them. The research serves as a reference for other municipalities with an interest in analysing projects related to the decision-making process, strategies, information, public services, and use of its IT resources. The study is also a contribution to academic knowledge in relation to the study of public policies related to urban management. Finally, the study contributes to the field of research related to the study of strategic digital city, serving as a basis for future studies in this discipline.

Keywords: strategic digital city; decision-making process; municipal strategies; municipal information; municipal public services; information technology

\section{Introduction}

The proper use of IT from the city manager could engage the citizens in the decision-making process. The citizens' engagement, such as a participatory democracy model, could be facilitated through access to electronic public services, transparency, and information [1-3].

While cities are trying to modernise to fit the new reality related to technological advancement, they also must deal with basic issues such as sanitation, disordered growth, crime and violence, transportation, and worsening social inequalities. Such issues require city managers to implement innovative solutions in an increasingly competitive scenario between cities [4-8]. These problems can be intensified through the lack of planning and inadequate implementation $[9,10]$. 
Making appropriate use of the latest information technologies, effectively aligning organisational objectives and the needs of the information society to promote governance constitutes a major challenge to public managers $[1,11,12]$. Another problem for cities is the identification of municipal public services as a priority and the proper balance between social demands and municipal budgets [13]. Consequently, the issues related to public services can be linked to distribution rules or their outcomes [14,15].

The objective of this study was to analyse the decision-making processes, strategies, information, public services, and information technologies in relation to strategic digital city issues in the city of Guarapuava.

The justifications of the research are related to strategies of electronic governance and administrative processes that when adapted to the dynamic of the digital age result in a real improvement of public services. Municipalities that invest in electronic governance, provision of free access points, and adequate and efficient training in the use of new technologies can convert these investments into benefit for their citizens. The most appropriate model of public management is one that is done in an efficient, effective, productive and quality way $[4,16]$.

Digital inclusion is a means of citizen engagement and participation in municipal management, in the discussion of the problems of the city, and in the search for solutions [17-20]. Cities that make better use of modern technologies will be better prepared to thrive in the context of the information society $[8,11]$. This preparation is related to the planning of information technology and the digital city, with electronic government, yielding the most competent management of the cities, city halls, and organisations. The success of municipal management is related to its ability to integrate different concepts and approaches of administration science in a model of public governance [21]. This administrative capacity involves the integration of different plans, agents, and resources with their technical and political challenges using conventional resources and information technology, rationally and effectively, resulting in competent management [10].

The effective use of modern information technologies and their alignment with government objectives and the expectations of the population constitute strategic elements of public management efficiency improvement $[1,12,19]$. This efficiency is associated with an appropriate prioritisation that meets the demands of the population and municipal budget, as well as clear definitions related to distribution rules or their outcomes $[14,15,22,23]$.

\section{Background}

Brazil, which occupies a prominent position in South America, saw its urbanisation process intensify in the mid-twentieth century [24]. Nowadays, the population of the urban area already surpasses the population of the rural zone, which is a common phenomenon in many countries around the world [25]. The state of Parana is one of the largest grain producing states in Brazil, and many cities in this state have had a predominantly agricultural vocation for many years. However, with the process of farm mechanisation and the exodus of people leaving the countryside towards the cities, they had to adapt to this new reality.

Guarapuava is an example of a centennial town that has been predominantly agricultural for a long time and now seeks to adjust to the population density and the new information age, reflecting the reality of other cities that have gone through the same process. The municipality, in addition to its strategic position in the central region of the State of Paraná, between Foz do Iguaçu and Curitiba, also has a historical significance to the State. After being split from the village of Castro, the settlement was named Freguesia de Nossa Senhora do Belém in the year 1819; later, in the year 1852, it was elevated to the category of village, and, seven years later, the district of Guarapuava was created [26]. Even before becoming a municipality, it stood out by its potential, having taken many steps in its development. Initially, the population grew through migration and the development of its agriculture, consolidating its vocation in this sector. More recently, its strategic position has strengthened with a diversification of potentialities going beyond agriculture, with claims to become a digital city $[27,28]$. 
The problem of this research lies in the fact that the Brazilian public administration context is difficult due to Brazil's dense population, large territory, and bureaucratic model. Another problem is related to the generation of information in towns, and its correct usage through information systems for demographic and social policy planning [19,29]. In addition, it is a big challenge to offer public services that meet the demands of a modern society connected in the information age [11]. Many cities around the world are in a similar condition. The new reality of many similar towns is challenging for municipal managers.

The concept of the strategic digital city has been used to study models of digital cities. A study related to the analysis of strategies, information, public services, information technologies, and strategic digital city projects was made in 115 Brazilian municipalities [30]. Similar studies have also been conducted in other cities such as Chicago in the United States, Barcelona in Spain, and Monterrey in Mexico [31-33].

\section{Theoretical Foundation}

The purpose of this study was to analyse the decision-making processes, strategies, information, public services, and information technologies concerning strategic digital city issues. This section covers the critical related concepts such as evidence-based decision process, strategic digital city, and its components.

\subsection{Evidence-Based Decision}

According to Braga [34], the decision-making process can be defined as "the process of thought and action that will culminate with a choice" by the decision-maker of acceptance or rejection of alternative courses of action. In addition, decision-making is of great importance in the administration of organisations, because a significant part of the act of administering involves decision-making and is one of the fundamental aspects of the leadership role. In summary, the performance of an organisation is closely related to the way decisions are taken by its managers.

Decision theory has grown out of several studies in various areas of knowledge into several related theories [35]. Decision theory can be studied from different approaches such as limited rationality, strategy, and policy, among others [36-40].

Decisions can also be classified according to the degree of structuring: fully structured, semi-structured, and unstructured [41]. A fully structured decision would be the kind of decision that would not involve the actions of a human manager such as automated decision-making procedures in computer systems. This type of decision is related to problems where the definitions and stages of operations to achieve a result are clear, repetition is always possible, costs are minimised, and returns maximised [42]. For this type of decision, information recorded from computer transactions, based on numeric data that are collected, stored, processed, and queried to identify trends, reporting, simulations and operating procedures are used [43]. The semi-structured type of decision would be decisions that involve both human and computer participation jointly. Finally, unstructured decisions would be those that depend only on a human manager [44]. This type of decision is characterised by the existence of complex and unscheduled situations, where the decision maker will have to create alternatives and implement them by means of a continuous process of learning, incorporating elements of cognition and self-organising $[36,45,46]$.

Evidence-based (EB) decision-making, with practices and management decisions based on evidence, arose in the medical field over the last 20 years, developed by a group of researchers led by David Sackett McMaster at McMaster University in Canada [47]. The main idea in this concept is that good decisions or qualities should be based on a combination of critical thinking and the best evidence available. Evidence-based decisions are structured in six main steps: ask, acquire, appraise, aggregate, apply, and assess. This evidence is drawn from four main sources: scientific literature, organisational data, professional experience, and target audience (stakeholders) [48].

In evidence-based decision making, the main focus is actions that are undertaken to acquire reliable evidence. The first step is proper formulation of questions that best sum up the problem in 
the search for evidence. The search for evidence is a systematic process. Appraise or analyse involves a critical judgement of the reliability and relevance of the evidence found. Aggregate is related to the process of organising and accumulating evidence giving weight to the importance or relevance to each piece of evidence. Apply involves incorporating the evidence into the decision-making process. Finally, Assess involves the evaluation of the result of the decision taken [47].

\subsection{City, Digital City, and Strategic Digital City}

The city concept is huge; however, there is a point of convergence between these different concepts. In other words, it is a material space of social relations; cannot be confused with the urban; is the place where the citizenship makes sense; a mix of representations; can be a reference of place; is one of the stages of policy; and is where daily dilemmas are manifested [49-51]. With the advent of information technology and the information society arise new concepts associated with the city: cyberspace, cyber city, virtual city, electronic city, and digital city. Similarly, as with the concept of city, the concept of digital city is diversified, and there is no uniformity with respect to its nomenclature among its various authors $[3,7,18]$.

The digital city concept arose during the 1980s and since then has been used for different approaches that range from electronic portals to virtual representations of cities [50]. Examples of digital city projects in the literature include De Digitale Stad in Amsterdam in the Netherlands; Digital Bologna, in Bologna, Italy; Digital Helsinki, in Helsinki, Finland; Digital Kyoto, in Kyoto Japan; and Digital Netville in Toronto Canada, among others [11,52-55]. In Brazil, a digital city project arose in 2001 as a public policy program sponsored by the Ministry of Communications (MC) to promote digital inclusion and expansion of e-government services in the municipalities [56,57].

The term strategic digital city (SDC) is proposed in [10] as a broader concept for a digital city, going beyond implementing features of information technology (IT) through infrastructures of hardware and software. According to Rezende [10], the SDC "can be understood as an application of information technology resources in the management of the city (city hall, municipality, public organisations and government agencies) and also in the availability of information and public services to citizens". Rezende [10] claimed SDC can be implemented as a broad and comprehensive project involving strategy elements, information, services and information technology in an integrated manner. Therefore, for a municipality be characterised as SDC, it must go beyond providing Internet access to its citizens.

\subsubsection{Municipal Strategies}

The concept of strategy is broad, and several authors define it from different perspectives. It can be regarded as a plan, pattern, position or perspective [58]. According to Campos (2016), strategy is "a means to reach to an end (...) the strategy is never an end, but a way to achieve certain goals". According to Rezende [10], "the strategy can be understood as a means, ways, activities or paths to meet municipal goals". In the context of the city, according to Rezende [10], it is "a continuous and iterative process that aims to keep the municipalities, prefectures and public organizations as a set of properly integrated to its environment". Additionally, it can be understood "as a standard or a plan that integrates cohesively the goals, policies and actions of a municipality".

Strategic management in a city demands managers who are alert to the processes and steps involved in its administration [59]. In this way, there are five steps in the process of strategic management in the context of the city: environmental analysis, the establishment of guidelines, the formulation of strategies, the implementation of strategies, and the elaboration of strategic controls $[10,60]$.

\subsubsection{Municipal Information}

Urban managers recognise that information is essential for the decision-making process and management of the cities. A large volume of information is generated all the time and circulates among the different systems around the city such as Information Business (IB), Geographic Information System (GIS), or Public Management Information System (PMIS), among others. This information 
may be linked to the flow of vehicles on a highway, data on distribution and billing of electricity or water consumption, or criminal occurrences in a given region, among many others. This information is important not only to administrators of cities, but also to citizens, since, for example, drivers can be informed about traffic and road conditions, helping them to decide which is the best route to follow; consumers receive real-time information on energy consumption, water and gas, and thus, on the basis of this information make decisions regarding the use and consumption of these resources; and citizens can be alerted to possible climate changes or emergency occurrences that can guide them through the adoption of certain procedures or actions for their safety and their family [21,61].

\subsubsection{Municipal Services}

In the literature, it is possible to find several definitions for public services. Cretella [62] defined it as "the activity that the public legal person exerts, directly or indirectly (delegation), for the collective needs, through peculiar procedures to public rights". However, Bandeira de Mello [63] defined it as any activity providing utility or convenience from public administration.

Municipal services can be understood as public services offered to citizens by means of its administration [13]. In the context of the SDC, these services are offered through informational resources in an IT infrastructure $[10,64]$. The idea of using technological resources for the provision of digital services is not new, dating back to the 1970s, but has become much more popular with the advent of the Internet. An example of this effort is the emergence of the e-government concept, which encompasses the idea of using technology to provide public services to the citizens in an interactive way; this idea arose in Brazil in the year 2000 [65,66].

\subsubsection{Municipal Information Technology}

Information technologies are computational resources (hardware, software, telecommunications, and data and information management) that make up the computational and informational structure, which is used in a integrated way in the management of the city [10].

Projects of digital cities, in general, aim for the collection, structuring, and provision of information by digital means to enable citizens to interact among themselves and with the government [4]. It is not within the scope of the SDC model to define the way this process of interaction should occur, or even set out a model of participatory governance. However, SDC projects emphasise the need to use IT resources for the provision of municipal services to the citizens to facilitate their lives in terms of time, space, and quality of information with the possibility to put the citizen as an active actor in the process of municipal management [10].

\section{Research Methodology}

This study used a descriptive research survey method for the gathering of information concerning the municipality of Guarapuava and the description of its characteristics using a previously defined research protocol [67]. This was a deductive method because it was based on an already defined theory with an objective of determining whether the phenomenon can be explained from the paradigm [68-71].

The main theories used to support critical concepts discussed in this research were based on a bibliographical study [68,71]. For the bibliographic survey and creation of the bibliographic portfolio, the databases surveyed were Scopus, Web of Science (WoS), ISA, Scielo, and Google Scholar. It is a quantitative research approach since it proposes to use a statistical tool in gathering, treatment, and analysis of data $[69,70]$.

The study also used documentary research for the survey of data related to the city of Guarapuava that was the object of this study. Two factors were decisive in the choice of this last technique: The first is related to the geographical location of the studied municipal district and characteristics of the object of study. The second is related to the fact that the study of SDC attempts to identify two dimensions that are fundamental for their characterisation, namely Information and IT. Thus, the amount of 
information provided by the municipality, as well as the means used by itself already constitute objects of investigation and analysis [30].

The study was undertaken in four phases: preparation of the research, data collection, data analysis, and documentation of the research.

The scope of research is related to the city of Guarapuava, located in the State of Paraná [69].

Quantitative aspects of the study involved sampling, data analysis and tabulation [72]. The contents of the municipal website and official documents of the municipality of Guarapuava were studied [73].

The research protocol, for its rigour, aimed to give the study its validity [74,75]. It should contain the main elements, procedures, and general rules to be followed in conducting the research, relating the existing constructs with their respective variables and questions [68,71]. A research protocol (Table 1) involving decision constructs, evidence, and a strategic digital city definition was developed for the research of the city.

Table 1. Research protocol structure.

\begin{tabular}{|c|c|c|c|}
\hline Variable & Question & Unit & Technique \\
\hline Decision-making process & What is the type of decision process? & Type & Survey \\
\hline Decision type & What is the type of decision? & Type & Survey \\
\hline Hierarchical level of the decision & What is the hierarchical level of decision? & Level & Survey \\
\hline \multicolumn{4}{|c|}{ Evidence construct } \\
\hline Scientific research & What is the name of source? & Name & Survey \\
\hline Public agent & Is used as evidence source? & Yes/No & Survey \\
\hline Citizen & Is used as evidence source? & Yes/No & Survey \\
\hline Municipal data & Is used as evidence source? & Yes/No & Survey \\
\hline \multicolumn{4}{|c|}{ Strategic digital city construct } \\
\hline Name of IT resource & What is the name of IT resource? & Name & Documental analysis \\
\hline
\end{tabular}

The decision construct consists of variables, decision-making processes, decision types and hierarchical levels of the decision. The construct evidence consists of variables: domain type, scientific research, public officer, citizens, and municipal data. The digital city strategic construct consists of variables: name of the strategy, name of the information, public service name and name of the means of IT $[68,71]$. A research guide was prepared from the construct and its variables for use in surveys, interviews, or documentary analysis.

To allow us to draw comparisons between elements of the research objective based on the construct and its variables, a survey, interviews, and documentary analysis were done between January and July 2018.

\section{Results and Analysis}

The results and analysis of the data are subdivided into subsections according to the decision construct, evidence, and strategic digital city concept. In addition, some variables were related to the municipal theme. This municipal theme is based on the definition of Rezende [10], who described the municipal theme as "macro activities present in all municipalities, city halls and public organisations necessary to its integrated and effective functioning". For the purpose of standardisation, the following themes were used: administration, agriculture, science and technology, trade, culture, divulgation or marketing, education, sports, financial, government, housing, industry, legal, leisure, materials or logistics, environment, construction, planning, human resources, rural, sanitation, health, safety, municipal services, social, transit, transportation, tourism, and urban [10]. 


\subsection{Analysis of the Decisions}

The decision-making process in the municipality of Guarapuava was identified through a survey carried out with the participation of 23 respondents, and data collected in the survey are represented in the following subsections. The city hall administration defined these 23 participants as the most representative stakeholders' group. Eventually, the sum of some answers will not total 23 because of the abstention in the response of some question.

\subsubsection{Analysis of the Decision Makers}

For the decision makers variable, the research sought to identify the profile of the decision makers considering the gender, age, time of professional experience as an administrator, occupation, educational level, and area of expertise.

The surveyed data showed that the decision makers' profile is mostly gender balanced with females having a small majority with 12 respondents compared to 11 males. Most participants are aged between 30 and 59 years, with seven aged 30-39 years, six aged 40-49, and seven aged 50-59. Of the 23 respondents, 14 occupy the post of manager. Most hold post graduate degrees, with 12 at the lato sensu level and two in a strict sense at the level of master. The operation area is well diversified involving roles in strategy, finance, change management, marketing, process, quality, human resources, and general administration. However, the majority also act in other areas not mentioned in the survey.

\subsubsection{Analysis of Decision-Making Processes, Types of Decision, and Hierarchical Levels}

In Brazil, municipal decisions focus on the legislative and executive powers. It is a representative model where the legislature is composed of councillors acting in the City Hall, and the executive consisting of the mayor, deputy mayor, and secretaries. The municipal administration is also composed of other agents, some in temporary positions and others permanent. The citizen has a vital role in the municipal decision-making process since he is the one who elects his representatives to act as mayor, deputy mayor, and councilman.

Because of the scenario that characterises Brazilian municipalities, it is possible to conclude that the city of Guarapuava is composed of different models of decision-making processes. They are processes that involve the citizen in the choice of its representatives, and in the decisions that are taken by them and by the others that make up the legislative and executive structure.

Analysing how managers decide in various departments, functions, and hierarchical levels, it was possible to identify distinct types of decision-making processes employed. The kinds of decisions identified in the search were semi-structured and unstructured. No fully structured decision was identified in the research. From the data collected, it was possible to identify at least two hierarchical levels of decisions with the strategic and tactical level.

\subsection{Analysis of the Evidence}

\subsubsection{Analysis of Domain Types}

The research revealed that 15 of the 23 used institutions as a source of evidence for the decision-making process, 22 used personal experience, 19 used the knowledge acquired in formal education, four used insights provided by experts, six used tips from colleagues, 13 used literature about management, 11 used scientific research results (scientific data), six used citizens and five mentioned using other sources. Thus, it appears that work experience is a major source of evidence for the survey participants, followed by knowledge acquired in formal education and institutions. On the other hand, citizens, tips from colleagues, and insights provided by experts are sources less used by respondents.

From the data presented in Table 2, it is possible to verify that, while the organisation's internal colleagues, trainers, literature, scientific research and target audience are queried frequently as sources of knowledge, colleagues and external consultants are consulted rarely. In addition, it turns out that the Internet is used as a daily source of knowledge to aid in the decision-making process. In addition 
to the sources listed in Table 2, some of the interviewers mentioned also using other institutions, conferences, events, seminars and training courses as sources of knowledge for decision-making processes.

The data presented in Table 3 indicate that most of the journals of the literature on professional administration are unknown to the majority of the participants of the survey. On the other hand, there are some cases in which the journal is known despite not having been read, or in some cases occasionally read. Only one of the respondents mentioned a frequent reading of the periodical Economics \& Management. In addition to the journals cited, one of the respondents mentioned reading the journal Magazine New School.

Table 2. Frequency on consultation of knowledge sources.

\begin{tabular}{lcccc}
\hline Source & Never & Rarely & Frequently & Daily \\
\hline Colleagues inside their organisation & - & 4 & 10 & 8 \\
Colleagues outside their organisation & 2 & 9 & 7 & 1 \\
External Consultants & 2 & 10 & 3 & 2 \\
(Trainers) Professors/instructors & 1 & 7 & 9 & 2 \\
Internet & - & 4 & 7 & 9 \\
Literature about management & - & 6 & 10 & 3 \\
Scientific research & 5 & 4 & 7 & 3 \\
Public target & 1 & 5 & 9 & 6 \\
\hline
\end{tabular}

Table 3. Frequency on consultation of professional literature.

\begin{tabular}{lcccc}
\hline Periodical & Do not Know & Knows, But Never Read & Knows, Occasional Reading & Knows, Frequently Reading \\
\hline Forbes & 5 & 8 & 3 & 1 \\
Harvard Business Review & 9 & 7 & 3 & - \\
Company Administration Magazine-CAM & 10 & 3 & 2 & - \\
Contemporary Administration Magazine-CAM & 12 & 2 & 4 & - \\
Electronic Magazine of Administration-EMA & 10 & 3 & - & - \\
Brazilian Business Review-BBR & 13 & 2 & 2 & - \\
Public Administration Magazine-PAM & 9 & 1 & 3 & - \\
Management Magazine of USP-MM-USP & 12 & 2 & 3 & - \\
Magazine of Administration and Innovation-MAI & 10 & 3 & 4 & - \\
Brazilian Magazine of Business Management-BMBM & 11 & 7 & & \\
Economics \& Management-E\&M & 8 & & \\
\hline
\end{tabular}

\subsubsection{Analysis of the Scientific Research Variable}

From the data collected, it was possible to identify that scientific research is used as a source of evidence; of the 23 surveyed, 16 mentioned that they know Google, nine know the SciELO, one knows EBSCO, no one has knowledge about the ISI Web of knowledge (Web of Science), one knows ProQuest and no one has knowledge about the Elsevier Foundation. Thus, it turns out that most respondents are familiar with Google and the SciELO Scientific database (Table 4).

The respondents also revealed that the Internet is used frequently to search for scientific articles. Further, the research is made to search for issues related to the themes: foster family, transit, education and school management, quality in the school bus, management, evaluation, curriculum, pedagogical training, innovative projects, inclusion, school feeding, service for students with special dietary needs, relocation of people within the same structure, environmental law, environmental engineering, environmental chemistry, public policies for gender equity, attention to women's health in situations of violence, gender diversity, improvement of the business environment for micro and small enterprises, behavioural neuroscience, domestic violence, service flow, psychology and violence against women, centre of reference of attention to women, monitoring of public services, and social control module. 
Table 4. Known scientific database.

\begin{tabular}{lc}
\hline Database & $\#$ \\
\hline Google escolar & 16 \\
SciELO & 9 \\
EBSCO & 1 \\
ISI Web of knowledge (Web of Science) & - \\
ProQuest & 1 \\
Elsevier & - \\
\hline
\end{tabular}

Concerning knowledge related to applied scientific research, it was found that more than half of the respondents have no experience in conducting scientific research. Despite this, more than half of those surveyed reported having received formal education with a focus on scientific research. The survey also found that respondents believe that more than $50 \%$ of their daily routine as manager is related to scientific discoveries.

Table 5 shows that the terms used in scientific research are the most researched knowledge. The terms less known for some are confidence intervals, regression, and controlled study. With respect to the term methodology, 11 of the survey participants said they knew it and would be able to explain it to others.

Table 5. Familiarity with research terms.

\begin{tabular}{lccc}
\hline Term & Do not Know & Know & Know, and Can Explain to Others \\
\hline Study case & 1 & 13 & 8 \\
Quantitative & 1 & 13 & 7 \\
Qualitative & 2 & 12 & 7 \\
Correlation & 2 & 12 & 3 \\
Sample & - & 12 & 8 \\
Interval of confidence & 6 & 10 & 1 \\
Regression & 7 & 10 & - \\
Controlled study & 6 & 11 & - \\
Bibliography & 2 & 10 & 7 \\
Analyzes & 2 & 9 & 11 \\
Methodology & 1 & 10 & \\
\hline
\end{tabular}

In relation to agreement or disagreement with respect to some informed general expressions, the opinions were quite diverse. However, as can be seen in Table 6, about half of respondents disagree strongly with the following expressions: "Scientific research is theoretical, with few practical applications"; "Managers do not have time to read scientific articles"; "Managers do not understand scientific articles"; and "Managers are practical professionals with no interest in scientific research".

In addition, some argue that the reason that prevents managers from using scientific research are routine, self-indulgence, ignorance of applicability in their daily routines, belief that the management is practical and not theoretical, and ignorance about the theme.

Evidence-based management is often described as "the conscious, explicit and judicious use of the best available evidence when taking managerial decisions in organisations. The practice of evidence-based management means the integration of research evidence with individual managerial expertise in the context of the characteristics of the organisation, culture and preferences" [76]. With respect to the term evidence-based management (EBMgt), more than half said they know little. Some described it as the best and most appropriate decisions; examples purchased; making decisions from facts that validate the working profile adopted; using evidence from other cases and situations in decision-making; understanding that it is a search for information on other organisations and applying it coherently in their daily work; management based on facts that occurred in a given period; and making decisions from some knowledge in the area, primarily through research data.

Most survey participants said they have a positive attitude towards EBMgt; however, they argue that the position of their colleagues on the subject tends to be negative. 
Based on the results presented in Table 7, it is possible to see that in general the respondents are inclined to agree that EBMgt should be part of the routine of managers as good administrative practice and that the same should receive formal education in its usage.

Table 6. Current attitudes towards scientific research.

\begin{tabular}{|c|c|c|c|c|c|}
\hline Expression & $\begin{array}{l}\text { Strongly } \\
\text { Agree }\end{array}$ & $\begin{array}{c}\text { Agree } \\
\text { Partially }\end{array}$ & $\begin{array}{l}\text { Neutral } \\
\text { Neutral }\end{array}$ & $\begin{array}{l}\text { Disagree } \\
\text { Partially }\end{array}$ & $\begin{array}{l}\text { Strongly } \\
\text { Disagree }\end{array}$ \\
\hline $\begin{array}{l}\text { Each organisation is unique, therefore scientific } \\
\text { discoveries are not applied }\end{array}$ & 1 & 5 & 2 & 5 & 8 \\
\hline $\begin{array}{l}\text { Scientific research is theoretical, with few } \\
\text { practical applications }\end{array}$ & - & 4 & 4 & 6 & 7 \\
\hline $\begin{array}{l}\text { Scientific research is conducted by researchers } \\
\text { that do not have practical knowledge in the } \\
\text { everyday }\end{array}$ & 1 & 5 & 4 & 5 & 7 \\
\hline $\begin{array}{l}\text { Scientists search for theoretical themes with no } \\
\text { practical relevance }\end{array}$ & - & 3 & 5 & 3 & 11 \\
\hline $\begin{array}{l}\text { Managers do not have time to read scientific } \\
\text { articles }\end{array}$ & - & 4 & 4 & 3 & 10 \\
\hline Managers do not understand scientific articles & - & 3 & 3 & 5 & 10 \\
\hline $\begin{array}{l}\text { Managers are practical professionals with no } \\
\text { interest in scientific research }\end{array}$ & 1 & 2 & 4 & 1 & 13 \\
\hline Scientific articles are impossible to read & - & 4 & 2 & 6 & 9 \\
\hline
\end{tabular}

Table 7. Current attitudes towards EBMgt.

\begin{tabular}{|c|c|c|c|c|c|}
\hline Expression & $\begin{array}{l}\text { Strongly } \\
\text { Agree }\end{array}$ & $\begin{array}{c}\text { Agree } \\
\text { Partially }\end{array}$ & $\begin{array}{l}\text { Neutral } \\
\text { Neutral }\end{array}$ & $\begin{array}{l}\text { Disagree } \\
\text { Partially }\end{array}$ & $\begin{array}{l}\text { Strongly } \\
\text { Disagree }\end{array}$ \\
\hline $\begin{array}{l}\text { Evidence-based management does not apply to } \\
\text { managers and consultants because their } \\
\text { professions are based on practical experience } \\
\text { and implicit knowledge }\end{array}$ & - & 3 & 5 & 7 & 4 \\
\hline $\begin{array}{l}\text { Evidence-based management does not do justice } \\
\text { to the personal experience and to implicit } \\
\text { knowledge managers and consultants }\end{array}$ & 1 & 2 & 5 & 5 & 5 \\
\hline $\begin{array}{l}\text { Using evidence-based practices, consultants can } \\
\text { improve the quality of their advice to customers }\end{array}$ & 4 & 9 & 5 & 1 & - \\
\hline $\begin{array}{l}\text { Using evidence-based practices, managers can } \\
\text { improve the quality of their work }\end{array}$ & 3 & 11 & 3 & 2 & - \\
\hline $\begin{array}{l}\text { In the formal education of managers and } \\
\text { consultants, more attention should be given to } \\
\text { the evidence-based management }\end{array}$ & 2 & 12 & 4 & - & - \\
\hline
\end{tabular}

\subsubsection{Analysis of the Public Agent}

The survey data revealed that public agents are used as a source of evidence. Six of the respondents indicated that they use the advice of colleagues as a source of evidence. Moreover, 10 of the surveyed often resort to the colleagues inside the organisation as a source of information, whereas eight of the respondents use these daily.

\subsubsection{Analysis of the Variable Citizen}

The survey data revealed that the citizens are also used as a source of evidence. As presented, six of the respondents indicated that they use citizens as source of evidence. In addition, nine of the surveyed often resort to the audience as a source of knowledge, whereas six of the respondents use these daily. The target public mentioned in the survey may refer to the citizen when this is the object of interest of the decision to be taken. 


\subsubsection{Municipal Data Variable Analysis}

From the data collected, it was possible to identify that 15 of the surveyed reported that they use institutions as a source of evidence.

\subsection{Analysis of Strategic Digital City}

\subsubsection{Analysis of the Strategies in the Municipality of Guarapuava}

The 28 strategies in the municipality of Guarapuava available through documents at the city website are classified as government and administration; social; sports; leisure; housing; industry and trade; tourism; agriculture; environment; urban; transportation; education; culture; health; security; human resources; administration and marketing; and safety. Analysing the strategies, it was realised that there is more concentration on projects related to government and its administration. However, we did not find any strategy related to areas such as science and technology. Even though this aspect can be improved, based on the analysis, we can conclude that the municipality meets the requirement strategies defined in the SDC concept.

\subsubsection{Analysis of the Information in the Municipality of Guarapuava}

The 48 identified information sources available to the citizens from the municipality of Guarapuava are available on the City Hall social networking and transparency portal. This variable reveals a considerable amount of information offered by citizens through different channels. The city administration has made effort to be more transparent and share information with citizens. By means of this analysis, we can conclude that the municipality meets the requirement for information as defined in the SDC concept.

\subsubsection{Analysis of Public Services in the Municipality of Guarapuava}

The five identified public services available to citizens from the city of Guarapuava are: NFS-e, DEISS (Electronic Declaration system of service tax), Server portal (PRONIM), Municipal Ombudsman, and webmail. Offering electronic public services to their citizens reveals the effort of city administration to make citizens' lives easier. By means of this analysis, we can conclude that the municipality meets the public service requirement for the concept of SDC.

\subsubsection{Analysis of Information Technology Resources in the Municipality of Guarapuava}

The four forms of IT available to the public by the city of Guarapuava, as well as how to access them are: Municipal Ombudsman-156 (website/Tel), services via the portal (Website), social media (Web), and digital tree (Wi-Fi). In June 2018, the Facebook page of the Prefecture had 21,184 followers, on Instagram 3447 followers, and on YouTube channel 139 subscribers. Information technologies resources can be used to wire citizens to the cloud. The analysis revealed the effort of the city to include citizens in the digital era, and its attempt to be connected with them. Based on it, we can conclude that the municipality meets the requirement means of IT as defined in the concept of SDC.

\subsection{Discussion}

The analyses revealed through the survey and documentary analysis that the decision maker variables, decision maker process, decision type and hierarchical level of the decision of the construct decision, as well as the variables of the domain type, scientific research, public officer, citizen and municipal data of the evidence construct, and finally the strategic variables, name of the information, public service name and name of the means of IT of the Digital City Strategic construct are all present and contemplated.

Therefore, it is possible to check the presence of different decision-making processes in the municipality by means of profiles and hierarchical levels, showing that the sources of evidence for 
decision-making come from the internal and external domains, indicating, however, that the citizen could have more participation as a source of evidence for the decision-making process.

The municipality has made use of social networks for greater engagement with citizens. However, the use made of social networks is for information purposes only. Given the municipality's failure to involve citizens in its decisions, social networks could be used for this purpose. That is, the city could use social networks to collect suggestions and meet the demands of its citizens. Thus, the citizens as a source of evidence in decisions made by the municipality would have a more active role.

Despite the EBMgt knowledge and the use of evidence for decision-making, there is insufficient knowledge and use of the main sources of scientific information, despite the interviewees' indication of an academic background with support for this type of data.

Regarding to SDC, the variables that constitute the strategic digital city construct are verified to be present in the municipality.

Although all the variables that contemplate the SDC construct have been identified, we can highlight some points as suggestions. The information available to citizens can be expanded, especially concerning the transparency portal that could be more intuitive and friendly to ordinary citizens. The city could increase IT resources offering more public Internet access in other public places with a high concentration of citizens. Although these SDC variables are present, in numerical terms, they can be expanded to suit the number of citizens in the municipality. However, some municipal public services that could become digital public services exist.

In related studies of SDC, it is found that, in general, the variables that make up the construct SDC are present. However, it is important to consider whether the amount recovered is compatible with the city size, or its number of inhabitants.

Indeed, checking or applying this model should take into account some limiting factors. The size of the municipality, sample, available data, data quality, access to information, and willingness of public agents to participate in a survey are factors that also limit the scope of the research.

\section{Conclusions}

The history of the municipality of Guarapuava from its origin presents a continually evolving process related to its urban area expansion, population density, as well its economic and social development. In the contemporary era of information, a critical challenge for city managers is to meet the demands of citizens at the same pace as the development of the resources of information technology.

The objective of this research study was achieved. The results obtained show that, in the city of Guarapuava, there are at least 28 strategies in 16 different thematic areas: 48 types of information and public services, using four means of IT with emphasis on the use of social networks. Besides, according to the interviewees, the decision-making process of the city relies mainly on professional experience, formal education, and institutions as sources of evidence. This finding shows that the variables of the decision maker, decision making process, decision type and hierarchical level of the decision of the decision construct, as well the variables domain type, scientific research, public officer, citizens and municipal data of the construct evidence, and finally the strategy variables, name of the information, public service name and name of the means of IT of Digital City Strategic construct are all present and developed.

This work is a contribution to the city providing an analysis within the dimensions studied; it will serve as a basis for a wide discussion about the implementation and provision of resources in question. The study serves as a reflection to the managers and a basis for analysis of the effectiveness of actions in relation to the proposed objectives. The data received can serve as a starting point for deeper analysis about each of the constructs analysed, according to its variables.

The research also serves as a reference for other municipalities with an interest in analysing projects related to the decision-making process, strategies, information, public services, and use of its IT resources. Further, it also contributes to a better understanding of how these elements make up the concept of SDC and thus can be used for future projects with means to make the city a SDC. 
The study is also a contribution to academic knowledge in relation to the study of public policies related to urban management. This research approached the issue of urban management through the aspect of SDC, thus providing another look at the problem, while at the same time it presents alternatives for understanding the topic from the point of view of integration of constructs used and their variables.

Moreover, the study contributes to the field of research related to the study of SDC, serving as a basis for future studies in this discipline. This study can be replicated in other municipalities, using its constructs and variables to fit the focus of the study in question, to broaden the analysis according to the object of study or research purpose.

The survey method is a limitation since it is based on the amount of data available and provided by the municipalities studied; naturally, the more the Brazilian municipalities adjust current legislation with respect to access to information, the better will be the quality of survey data in this method.

The conclusion reiterates that, although there is no homogeneity in the variables studied, the existing decision-making procedures in the municipality use evidence from the internal and external domains, professional experience, data generated by institutions, external professionals, citizens, and scientific research through publications. Public information and services are offered to citizens by means of information technology resources, including different municipal strategies, which can assist the management of the city and enhance the quality of life of citizens.

Funding: This research received no external funding.

Conflicts of Interest: The author declares no conflict of interest.

\section{References}

1. Cunha, M.A. Survey on the Use of Information and Communication Technologies in Brazil 2005-2009, 1st ed.; CGI.br-Brazilian Internet Steering Committee: Sao Paulo, Brazil, 2010; p. 73.

2. Scott, A.J.; Scott, A.J. Global City-Regions; Oxford University Press: Oxford, UK, 2001.

3. De Sousa Fernandes, C.; Carniello, M.F. Análise estrutural do município de Mineiros/GO para implantação da cidade digital. Rev. Tecnol. Soc. 2017, 13, 132-151. [CrossRef]

4. Frey, K. Governança eletrônica: Experiências de cidades européias e algumas lições para países em desenvolvimento. In Internet e Política: Teoria e Prática da Democracia Eletrônica; UFMG: Belo Horizonte, Brazil, 2002; pp. 141-163.

5. Rezende, S.; Wajnman, S.; de Carvalho, J.A.M.; Heller, L. Integrando oferta e demanda de serviços de saneamento: Análise hierárquica do panorama urbano brasileiro no ano 2000 Integrating supply and demand of water and sanitation services: Hierarchical analysis of the urban Brazil in 2000. Eng. Sanit. Ambient. 2007, 12, 90-101. [CrossRef]

6. Neuman, M.; Hull, A. The Futures of the City Region. Reg. Stud. 2009, 43, 777-787. [CrossRef]

7. Lima, P.V.P.S.; Sousa, J.S.; Araújo, A.M.; Faustino, J.C.S.; Casimiro, F. Gestão municipal da segurança pública: Responsabilidade dos municípios brasileiros no combate à violência. Revista de Políticas Públicas 2015, 18, 399-414. [CrossRef]

8. Sathler, D.; Guedes, G.R. Análise urbana global: Aplicaçao do modelo de classe latente para as "leading world cities". Geografia 2012, 37, 391-408.

9. Fernandes, R.J.L.; Fernandes, R.J.G. A cidade digital vs a cidade inteligente: Estratégias de desenvolvimento sócio-económico e/ou de marketing territorial. In $2^{\circ}$ Congresso Luso-Brasileiro Para o Planeamento Urbano, Regional, Integrado e Sustentável; Universidade do Minho: Braga, Portugal, 2006.

10. Rezende, D.A. Planejamento de Estratégias e Informações Municipais para Cidade Digital: Guia Para Projetos em Prefeituras e Organizações Públicas; Atlas: São Paulo, Brazil, 2012.

11. Lemos, A. Cidade Digital: Portais, Inclusão e Redes no Brasil, 1st ed.; EDUFBA: Salvador, Brazil, 2007.

12. Santos Junior, S.; Freitas, H.; Luciano, E.M. Dificuldades para o uso da tecnologia da informação. RAE-Eletrônica 2005, 4.10.1590/S1676-56482005000200005. [CrossRef]

13. Schou, J.; Hjelholt, M. Digital state spaces: State rescaling and advanced digitalization. Territ. Politics Gov. 2018. [CrossRef] 
14. Shoup, C.S. Rules for distributing a free government service among areas of a city. Natl. Tax J. 1989, 42, $103-121$.

15. Mendes, C.C.; de Sousa, M.d.C.S. Estimando a demanda por serviços públicos nos municípios brasileiros. Rev. Bras. Econ. 2006, 60, 281-296. [CrossRef]

16. De Oliveira, D.d.P.R. Administração Pública: Foco na Otimização do Modelo Administrativo; Atlas: São Paulo, Brazil, 2014.

17. Toffler, A.; Alvin, T. The Third Wave; Bantam Books: New York, NY, USA, 1980; Volume 484.

18. Castells, M. The Rise of the Network Society; John Wiley \& Sons: Hoboken, NJ, USA, 2011; Volume 12.

19. Da Gama Torres, H. Demografia urbana e políticas sociais. Rev. Bras. Estud. Popul. 2013, 23, $27-42$.

20. Bailey, A.; Ngwenyama, O. The challenge of e-participation in the digital city: Exploring generational influences among community telecentre users. Telemat. Inform. 2011, 28, 204-214. [CrossRef]

21. Barns, S.; Cosgrave, E.; Acuto, M.; Mcneill, D. Digital Infrastructures and Urban Governance. Urban Policy Res. 2017, 35, 20-31, doi:10.1080/08111146.2016.1235032. [CrossRef]

22. Hero, R. The urban sen/ice delivery literature: Some questions and considerations. Polity 1988, 18, 659-677. [CrossRef]

23. Neto, A.M. A distribuição dos serviços públicos: Teorias e evidências. Indicadores Econômicos FEE 1992, 20, 115-124.

24. Gratius, S.; Saraiva, M. Continental Regionalism: Brazil's Prominent Role in the Americas; CEPS Working Paper No. 374; 2013. Available online: https:/ / ssrn.com/abstract=2220097 (accessed on 3 October 2019).

25. de Brito, F.A.; de Pinho, B.A.T.D. A Dinâmica do Processo de Urbanização no Brasil, 1940-2010; Technical Report; Universidade Federal de Minas Gerais: Belo Horizonte, Brazil, 2012.

26. Schmidt, L.P. A (re) Produção de um Espaço Desigual: Poder e Segregação Socioespacial em Guarapuava (PR). 2009. 281 f. Ph.D. Thesis, Univ. Federal de Santa Catarina, Florianópolis, Brazil, 2009.

27. Silva, J.M. Processos econômico-sociais regionais e seus impactos sobre a estrutura urbana de Guarapuava-PR. Rev. Hist. Reg. 2007, 2.

28. Guarapuava. Prefeitura Municipal. Lei Municipal no 1949/2011, de 18 de Abril de 2011; Institui o Programa Guarapuava Digital (PMG): Guarapuava, Brazil, 2011.

29. Bartholomay, P.; de Oliveira, G.P.; Pinheiro, R.S.; Vasconcelos, A.M.N. Melhoria da qualidade das informações sobre tuberculose a partir do relacionamento entre bases de dados. Cadernos de Saúde Pública 2014, 30, 2459-2470. [CrossRef] [PubMed]

30. Rezende, D.A.; Ribeiro, S.S. Análise das estratégias, informações, serviços públicos municipais e tecnologias da informação e suas relações com projetos de cidade digital estratégica nas capitais da região centro-oeste do brasil. Rev. Bras. Gestão Desenvolv. Reg. 2018, 14.

31. Rezende, D.A.; Kohls, J.B. Public services and electronic government Chicago's digital city. In Proceedings of the International Conference on Social Science and Management-ICSSM, Chicago, IL, USA, 14-16 March 2014.

32. Parteka, E.; Alcides Rezende, D. Digital planning of the city of Barcelona and its relations with the strategic digital city. J. Technol. Manag. Innov. 2018, 13, 54-60. [CrossRef]

33. Rezende, D.; Bustani, C. The urban districts and tourist improvement in the Strategic Digital City: The DistritoTec in Monterrey, Mexico. TURyDES Revista Turismo y Desarrollo Local 2018, 11.

34. Braga, N. O processo decisório em organizações brasileiras. Revista de Administração Pública 1987, $21,35-57$.

35. Pettigrew, A.M. The Politics of Organizational Decision-Making; Routledge: London, UK, 2014.

36. Mintzberg, H.; Raisinghani, D.; Theoret, A. The structure of "unstructured" decision processes. Admin. Sci. Q. 1976, 27, 246-275. [CrossRef]

37. Simon, H.A. Administrative Behavior; Simon and Schuster: New York, NY, USA, 2013.

38. Cohen, M.D.; March, J.G.; Olsen, J.P. A garbage can model of organizational choice. Admin. Sci. Q. 1972, 17, 1-25. [CrossRef]

39. Cyert, R.M.; March, J.G. A Behavioral Theory of the Firm; Englewood Cliffs: Bergen County, NJ, USA, 1963.

40. Meyer, J.W.; Rowan, B. Institutionalized organizations: Formal structure as myth and ceremony. Am. J. Sociol. 1977, 83, 340-363. [CrossRef]

41. Turban, E.; Aronson, J.E. Decision Support Systems and Intelligent Systems, 6th ed.; Prentice-Hall: Upper Saddle River, NJ, USA, 2001 
42. Efraim, T.; Jay, E.A.; Liang, T.P.; McCarthy, R. Decision Support Systems and Intelligent Systems. Available online: https://www.academia.edu/26910803/Decision_support_systems_and_intelligent_ systems (accessed on 3 October 2019).

43. Lahl, D. Make better decisions by analyzing structured and unstructured data together. Bus. Intell. J. 2011, 16, 9-16.

44. Dacorso, A.L.R.; Russo, R.d.F.S.M.; Silva, M.C.M.; de Araujo, G.F. A qualidade das alternativas em decisões estratégicas: Um estudo sobre criatividade e completude em decisões empresariais. Rev. Adm. Mackenzie 2010, 11. [CrossRef]

45. Mariotto, F.L. Mobilizando estratégias emergentes. Revista de Administração de Empresas 2003, 43, 78-93. [CrossRef]

46. Crow, J.J. Examining Cognitive Processes of Unstructured Decision Making. Ph.D. Thesis, Kansas State University, Manhattan, KS, USA, 2006.

47. Barends, E.; Rousseau, D.M.; Briner, R.B. Evidence-Based Management: The Basic Principles; CEBMa: Amsterdam, The Netherlands, 2014. Available online: https://www.cebma.org/wp-content/uploads / Evidence-Based-Practice-The-Basic-Principles.pdf (accessed on 3 October 2019).

48. Barends, E.G.; Briner, R.B. Teaching evidence-based practice: Lessons from the pioneers: An interview with Amanda Burls and Gordon Guyatt. Acad. Manag. Learn. Educ. 2014, 13, 476-483. [CrossRef]

49. Santos, M. Por uma Geografia Nova; Hucitec: São Paulo, Brazil, 1978.

50. Da Silva, M.T.C. A (ciber) geografia das cidades digitais. Scripta Nova Revista Electrónica de Geografía y Ciencias Sociales 2004, 8. Available online: https://www.raco.cat/index.php/ScriptaNova/article/view/63992 (accessed on 3 October 2019).

51. Da Costa Amedi, N. A cidade (res) significada: A ideologia de modernização de Cuiabá no período pós-divisão do Estado de Mato Grosso. Angelus Novus 2013, 4, 41-64. Available online: http:/ /www. periodicos.usp.br/ran/article/view/88864 (accessed on 3 October 2019).

52. Ishida, T.; Isbister, K. Digital Cities: Technologies, Experiences, and Future Perspectives; Lecture Notes in Computer Science; Springer: Berlin/Heidelberg, Germany, 2000.

53. Wellman, B.; Haase, A.Q.; Witte, J.; Hampton, K. Does the Internet increase, decrease, or supplement social capital? Social networks, participation, and community commitment. Am. Behav. Sci. 2001, 45, 436-455. [CrossRef]

54. Guerreiro, E. Cidade Digital: Infoinclusão Social e Tecnologia em Rede; SENAC: São Paulo, Brazil, 2006.

55. Leite, J. Da cidade real à cidade digital: A virtualização de estruturas urbanas na construção do ciberespaço público. Razón y Palabra 2006, 49, 39-50.

56. Brasil. Planejamento Estratégico Municipal e Desenvolvimento Territorial; Ministério do Planejamento, Orçamento e Gestão: Brasília. Brazil, 2014.

57. De Castro, J.G. Cidades Digitais: Uma Análise da Implantação Infraestrutura em seu Projeto-Piloto. Bachelor's Thesis, Universidade de Brasília, Brasília, Brazil, 2015.

58. Mintzberg, H.; Quinn, J.B.; Lampel, J.; Ghoshal, S. O Processo da Estratégia: Conceitos, Contextos e Casos Selecionados. Porto Alegre, 4th ed.; Bookman: Stockholm, Sweden, 2011.

59. Der Meer, A.V.; Winden, W.V. E-governance in Cities: A Comparison of Urban Information and Communication Technology Policies. Reg. Stud. 2003, 37, 407-419, doi:10.1080/0034340032000074433. [CrossRef]

60. Salvi, L.T.; Hardt, L.P.A.; Rezende, D.A.; Hardt, C. Novos desafios à administração estratégica de políticas públicas e projetos urbanos. Revista da FAE 2007, 10.

61. Harrison, C.; Donnelly, I.A. A theory of smart cities. In Proceedings of the 55th Annual Meeting of the ISSS-2011, Hull, UK, 17-22 July 2011.

62. Cretella, J. Enciclopédia Saraiva de Direito; Saraiva: São Paulo, Brazil, 1977.

63. Bandeira de Mello, C.A. Curso de Direito Administrativo, 1st ed.; Malheiros: São Paulo, Brazil, 2004.

64. De Siqueira, M.M. Redes sociais na gestão de serviços urbanos. Revista de Administração Pública 2000, 34, 179-198.

65. Borges, J.; Nascimento, J.; de Silva, H.P. Análise das informações disponibilizadas no portal de serviços e informações do Governo Federal. Diálogo Científico Administração Pública e Gestão Social 2005, 8, 147-158.

66. Jardim, J.M. Governo eletrônico no Brasil: O portal rede governo. Arquivística Net 2007, 3, $28-37$.

67. Ribeiro, S.S. Modelo de Proceso Decisório Municipal Baseado em Evidências no Contexto da Cidade Digital Estratégica. Ph.D. Thesis, Pontifícia Universidade Católica do Paraná, Curitiba, Brazil, 2018. 
68. Gil, A.C. Métodos e Técnicas de Pesquisa Social, 6th ed.; Atlas: São Paulo, Brazil, 2008.

69. Freitas, H.; Oliveira, M.; Saccol, A.Z.; Moscarola, J. O método de pesquisa survey. Revista de AdministraEccdeil ão da Universidade de São Paulo 2000, 35, 105-112.

70. Raupp, F.M.; Beuren, I.M. Metodologia da Pesquisa Aplicável às Ciências, 3rd ed.; Atlas: São Paulo, Brazil, 2006.

71. Marconi, M.A.; Lakatos, E.M. Fundamentos de Metodologia Científica, 8th ed.; Atlas: São Paulo, Brazil, 2017.

72. Santos, J.A.; Parra Filho, D. Metodologia Científica; Cengage Learning: São Paulo, Brazil, 2012.

73. Babbie, E. Métodos de Pesquisas de Survey; Editora da UFMG: Belo Horizonte, Brazil, 1999; Volume 1.

74. Martins, G.d.A. Business growth and development in Latin America: Issues, challenges and opportunities in the 21st century. Epistemologia da Pesquisa em Administração 1996, 1.

75. Yin, R.K. Case Study Research: Design and Methods (Applied Social Research Methods); Sage: London, UK; Singapore, 2009.

76. Rousseau, D.M. Is there such a thing as "evidence-based management"? Acad. Manag. Rev. 2006, 31, $256-269$. [CrossRef]

(C) 2019 by the authors. Licensee MDPI, Basel, Switzerland. This article is an open access article distributed under the terms and conditions of the Creative Commons Attribution (CC BY) license (http:/ / creativecommons.org/licenses/by/4.0/). 